$\underline{\xi}=-m$

\title{
Myocardial ischemia: narrative drug targets and management by ethnobotanicals
}

\author{
Amna Batool ${ }^{1 *}$, Umme Habiba Hasan ${ }^{2}$, Farha Abid ${ }^{1}$, Ambreen Malik Uttra ${ }^{2}$, Umer Maqsood ${ }^{2}$, Bushra Shaukat ${ }^{1}$ \\ ${ }^{1}$ Faculty of Pharmaceutical Sciences, Govt College University Faislabad-Pakistan \\ ${ }^{2}$ Faculty of Pharmacy University of Sargodha-Pakistan \\ *Corresponding author E-mail: amnabatoolramzan64@gmail.com
}

\begin{abstract}
Cardiac ischemia is characterized by imbalance between oxygen demand and its supply to myocardium owing to atherosclerotic plaques, which results in moderate to severe damage to heart function. Ischemic heart disease leads to cardiac arrhythmia and heart failure. Various therapeutic interventions, including lifestyle modification, pharmacological treatment options and surgical procedures are available. Besides these therapies, ischemic patients have to suffer from cardiac events repeatedly. Therefore, novel treatment modalities directed towards LDL cholesterol synthesis, oxidation of LDL, monocyte/macrophage recruitment, foam cells, platelet aggregation, cytokines and extracellular matrix comprising of smooth muscle cells have been found to be the promising targeted therapies. Moreover, drugs of ethnobotanical origin might be safer, effectual and economic, thus improving the quality of life.
\end{abstract}

Keywords: Cardiac Ischemia; Atherosclerosis; Treatment Protocol; Novel Drug Targets.

\section{Introduction}

Myocardial ischemia is characterized by decreased blood flow to heart muscle owing to limited or complete blockage of coronary arteries. Thus decrease in blood flow reduces oxygen supply to myocardium, diminishing its aptitude to pump proficiently. A rapid and rigorous obstruction of a coronary artery might guide towards heart attack. Moreover, myocardial ischemia may also lead to anomalous heart rhythms. Typical signs and symptoms of myocardial ischemia are elaborated in (Table 1) (Bhatti et al. 2006). Among ischemic disorders, coronary heart disease (CHD) is a foremost cause of morbidity and transience globally. As unremitting myocardial ischemia ensuing from CHD can cause stable angina affecting the normal life activities.

\begin{tabular}{|c|c|c|}
\hline $\begin{array}{l}\text { Myocardial ischemia } \\
\text { signs and symptoms }\end{array}$ & $\begin{array}{l}\text { Conditions causing } \\
\text { Myocardial ischemia }\end{array}$ & $\begin{array}{l}\text { Factors increasing risk } \\
\text { of myocardial ische- } \\
\text { mia }\end{array}$ \\
\hline $\begin{array}{l}\text { Left side chest pres- } \\
\text { sure and pain }\end{array}$ & Atherosclerosis & Tobacco \\
\hline Jaw pain/neck pain & Coronary artery spasm & Diabetes \\
\hline Shoulder /arm pain & Blood clotting & High blood pressure \\
\hline Clammy skin & Severe illness & High cholesterol level \\
\hline Nausea and vomiting & - & $\begin{array}{l}\text { Lack of physical activ- } \\
\text { ity }\end{array}$ \\
\hline Shortness of breath & - & $\begin{array}{l}\text { Obesity } \\
\text { Family history }\end{array}$ \\
\hline
\end{tabular}

\subsection{Epidemiological aspects of myocardial ischemia}

During 1990 to 2000, mortality ratio owing to cardiovascular disease has been found to increase from 14 to 16 million internation- ally (Murray et al. 1996). One of the fatal CVD is ischemic heart disease with prevalence of $6.8 \%$ in Pakistan and United States of America (Yusuf et al. 2001). Various epidemiological risk factors like; lack of appropriate exercise, improper diet, smoking, air pollution and possibly fetal childhood exposures may increase the risk of cardiovascular diseases in adulthood as depicted in (Fig. 1) (Singhal et al. 2004). In recent decades, obesity and smoking are also cardiovascular risk factors with indubitable global encourage.

\subsection{Pathophysiology of ischemic heart disease}

Although, substantial progress has been made in perceptive of the pathophysiology of ischemic heart disease (IHD) for the last three decades, but focused on the ACS (e.g., ST-elevation or unstable angina pectoris [UAP]) and percutaneous revascularization). In recent times, innovative approaches for understanding the pathogenesis of CCS have led to the development of new anti-ischemic therapies with narrative mechanisms of action (Pepine et al. 2007).

\subsubsection{Myocardial oxygen supply-demand balance}

Cardiac ischemia is termed as myocellular hypoxia or the condition ensuing from imbalance between oxygen abounding to myocardium and its demand. Clinically cardiac ischemia has conventionally been subdivided into the ACS and CCS as given in (Table 2 ). Acute coronary syndrome is characterized by unexpected decline in coronary flow and hence, myocardial oxygen supply. Furthermore, plaque injury for example, rupture, erosion and hemorrhage often superimposed on thrombosis or microembolism along with endothelial dysfunction reduce coronary blood flow and lead to acute ischemic myocyte injury (Libby et al. 2005) 


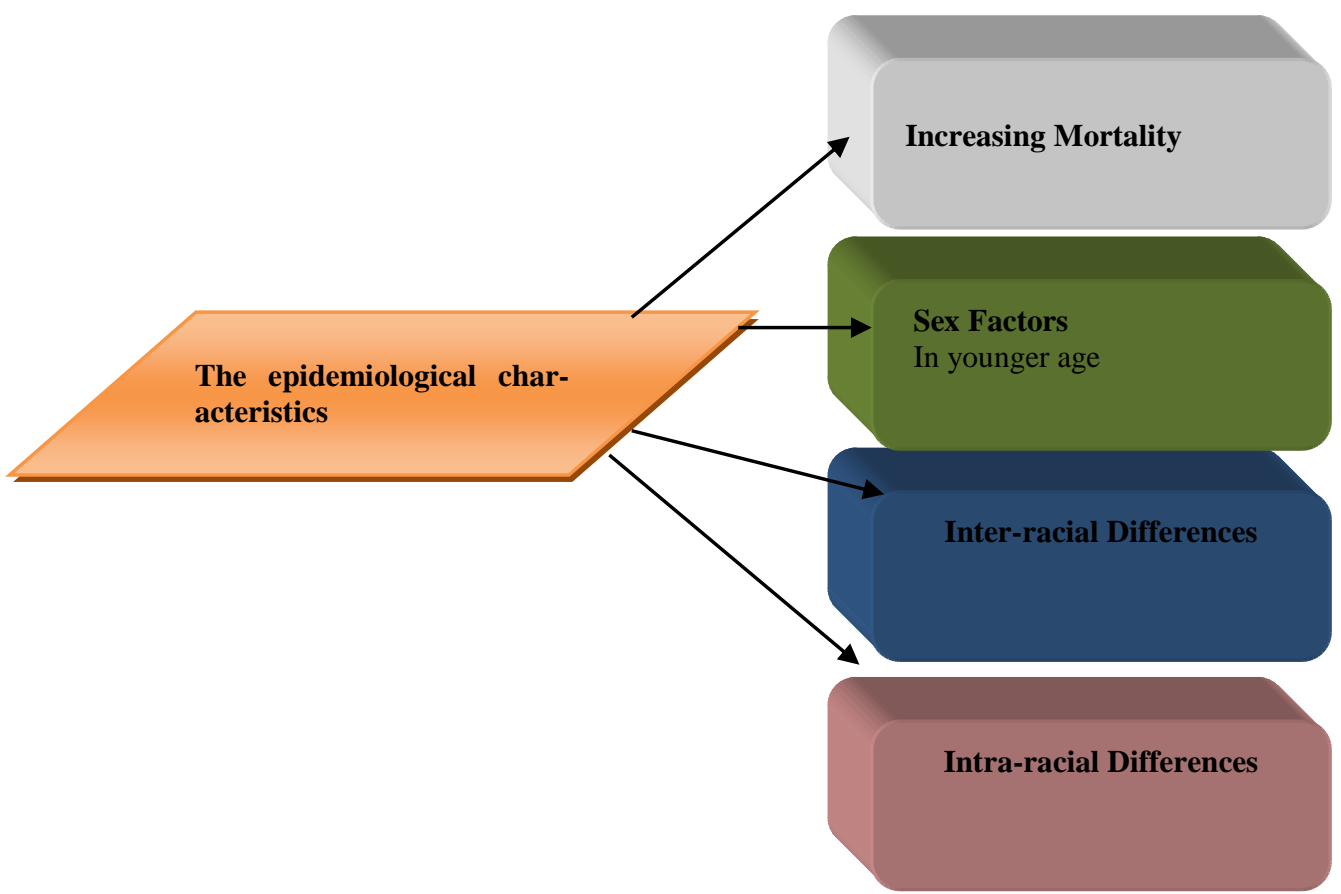

Fig.1: Epidemiological Aspects of Myocardial Ischemia

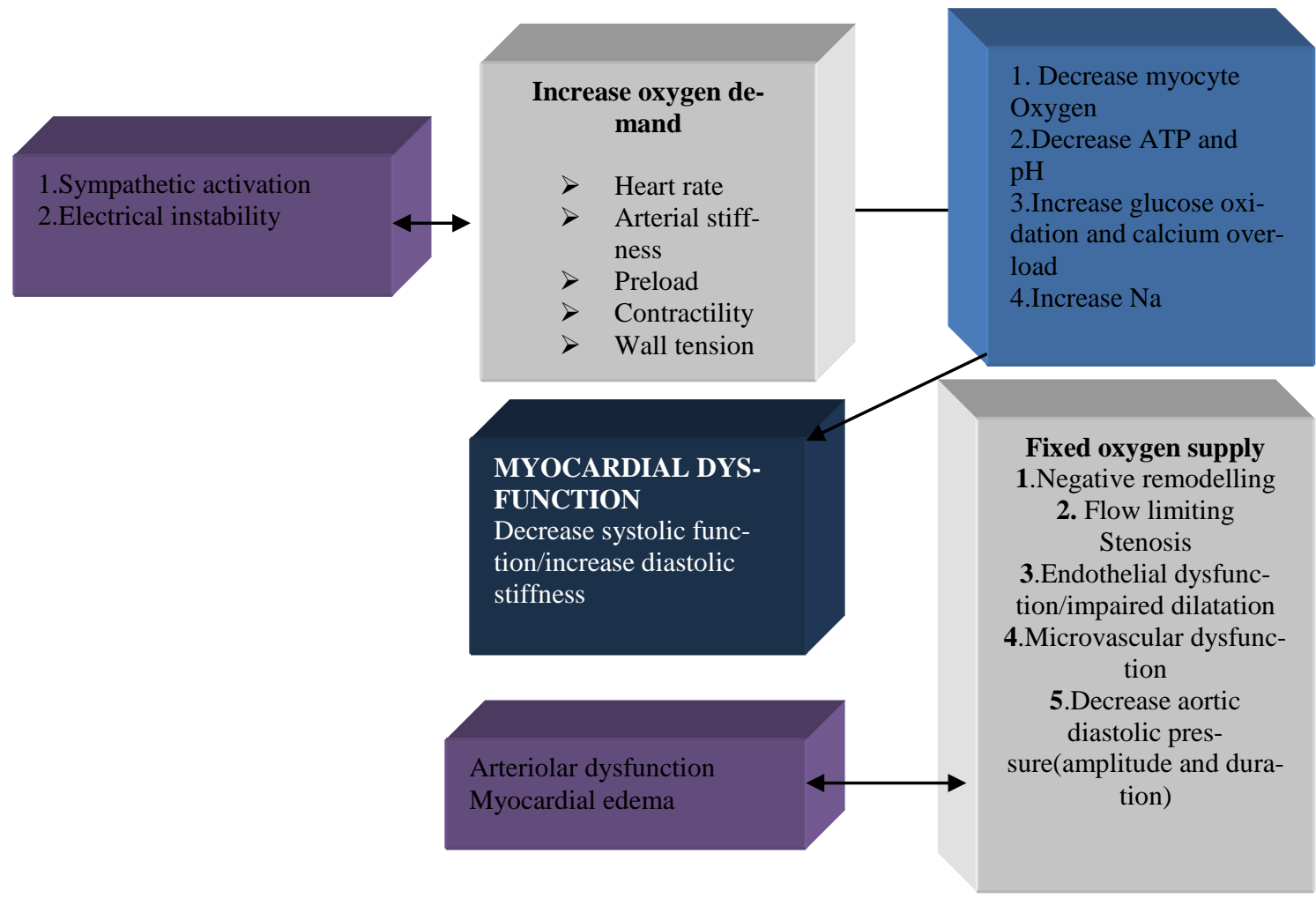

Fig. 2: Pictorial Pathophysiology Of Ischemic Heart Disease.

Table 2: Phenotypes of Myocardial Ischemia

\begin{tabular}{ll}
\hline Phenotypes of myocardial ischemia \\
\hline Acute coronary syndrome & Chronic coronary syndrome \\
An abrupt decline in coro- & An unexpected boost in myocardial oxy- \\
nary flow and hence, myo- & gen demand, in the situation of inade- \\
cardial oxygen supply, is & quate ability to increase myocardial oxy- \\
generally the mechanism of & gen supply, is typically the mechanism of \\
ACS. & ischemia in the CCS. \\
\hline
\end{tabular}

\subsubsection{Atherosclerosis}

Atherosclerosis accompanied by various complications is one of the most frequent causes of death. In atherosclerosis lesions, forming in the intimal layer constitutes a chronic inflammatory response to injury and results from relations between plasma molecules such as lipoproteins, cellular components and the extracellu- lar matrix of the arterial wall. Atherosclerosis chiefly involves plasma low density proteins cholesterol, monocytes, macrophages, endothelial cells and smooth muscle cells (Calvez et al. 2010). Process of atherosclerosis involves amassing of LDL cholesterol in the intimae and recruitment of circulating immune cells, e.g. monocytes. Monocytes differentiate into macrophages that phagocytose oxidized LDL and alter the fatty macrophages into foam cells as represented in (Fig. 3). Consequently, foam cells build up a subendothelial plaque which ultimately appears in the artery lumen and incites inflammatory response (Calvez et al. 2010). Moreover, macrophages in the intimae lead to the production of pro-inflammatory cytokines that enhance their recruitment (Tomkin et al. 2012). Furthermore, local hemodynamic conditions have notable collision on the earliest stages of atherosclerotic lesions 
like oscillating shear stress. Low wall shear stress and long retention times influence the formation of plaques.

\subsubsection{Cholesterol absorption and transport}

Mass of cholesterol is synthesized within the liver, and about 25 $\%$ in the intestine are absorbed from diet or reabsorbed from bile. From the intestine, cholesterol is transported to be liver by intestinally-derived apolipoprotein (apo B 48), a large lipid rich particle with a short half-life of approximately $90 \mathrm{~min}$. In addition, apo E is transferred to the chylomicron from high-density lipoprotein in the blood circulation and is partially hydrolyzed by lipoprotein lipase before taken up by the $\mathrm{B} / \mathrm{E}$ receptor on the liver as shown in figure 4 . Thus released cholesterol is again packed accompanied by de novo synthesized and liver derived cholesterol, triglyceride and phospholipids. It is solubilised by apo B 100 followed by excretion as very low-density lipoprotein (VLDL) into the blood stream. VLDL particles are hydrolyzed by lipoprotein lipase present in the capillary wall which removes most of the triglyceride, and particle becomes a VLDL residue. Low-density lipoprotein may be further converted to LDL. Moreover, Apo E is involved in removal of most of the hydrolyzed VLDL through LDL B/E receptor in the liver and then transferred back to HDL. Thus, LDL serves as a medium to supply cholesterol all over the body in order to keep cell viability and to provide cholesterol for the synthesis of the steroid hormones. Regulation of LDL is finely tuned, and HDL has a crucial role in reverse cholesterol transport and also protects LDL from oxidative degradation. The majority of cells are capable of synthesizing cholesterol through the HMG-CoA reductase pathway, when cholesterol absorption is diminished. Statins inhibit HMG-CoA reductase pathway. Reduced de novo cholesterol synthesis up-regulates the LDL receptor and stimulates LDL clearance which in turn stimulates cholesterol absorption from the intestine. The way by which cholesterol absorption takes place was established when ezetimibe, a compound that reduce serum cholesterol level, has been shown to bind to the brush borders of the enterocyte and to NPC1L1. Moreover, ATP binding cassette proteins (ABC) G5 and G8 in the intestine also control cholesterol absorption (Tomkin et al. 2012)

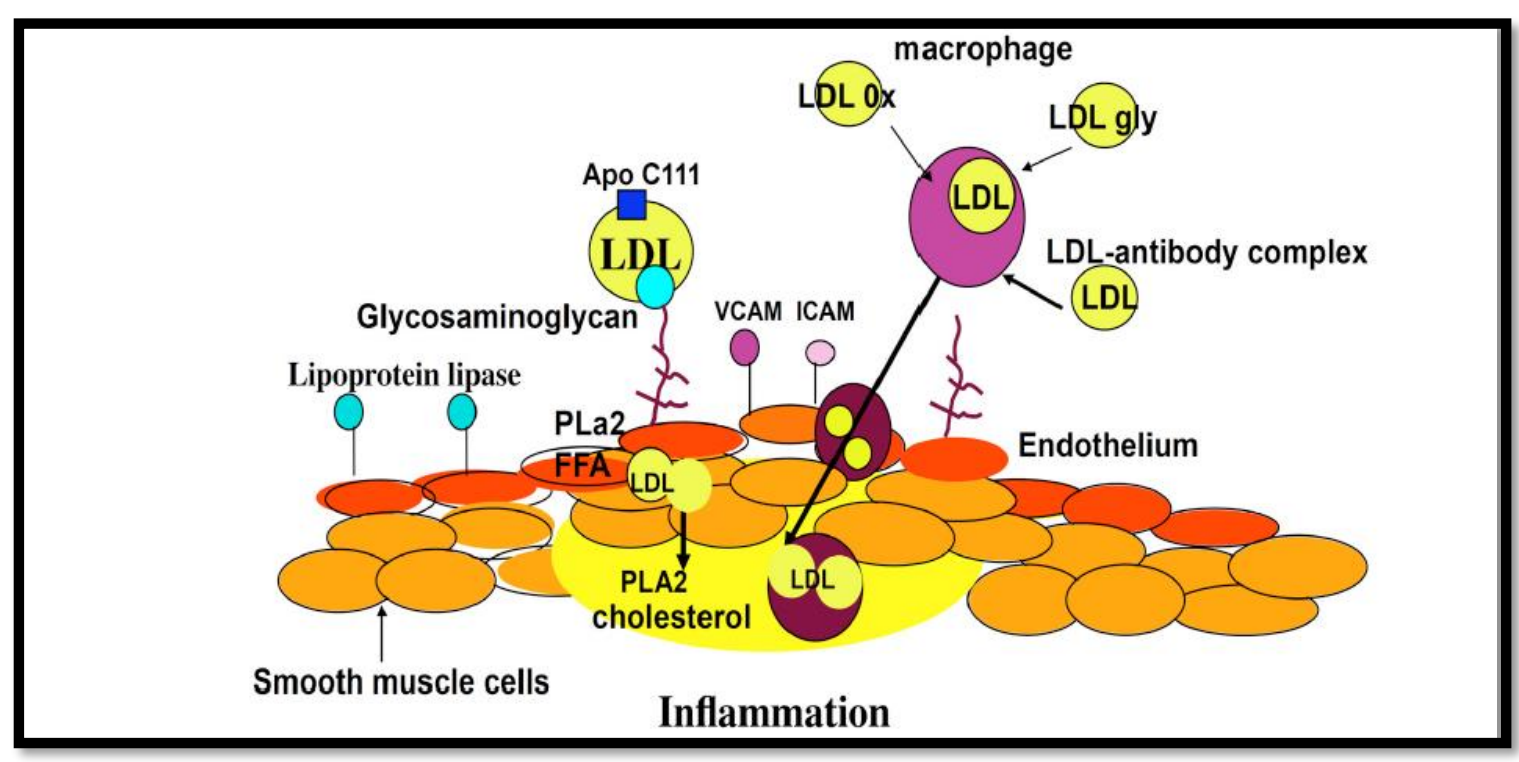

Fig. 3: Process of Atherosclerotic Plaque Formation (Adopted from Tomkin et al. 2012).

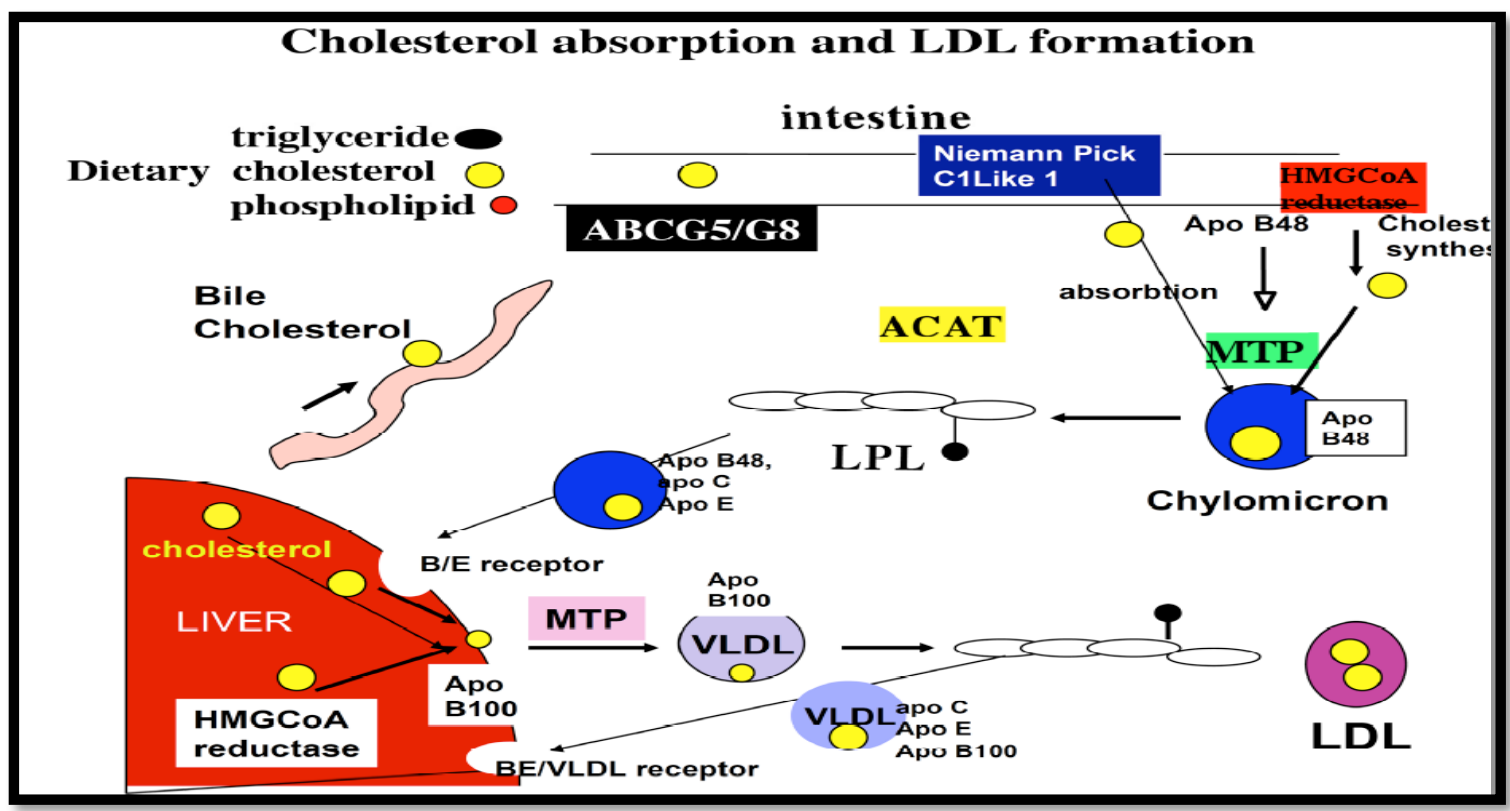

Fig. 4: Cholesterol Absorption and LDL Formation (Adopted from Gerald et al. 2012. 


\subsection{Complications faced by myocardial ischemia}

Ischemic heart disease is allied to severe heart complications as summarized in (Fig. 5).

\subsubsection{Heart attack}

Blockade of coronary arteries owing to atherosclerosis results in decreased blood supply and hence oxygen becomes deficient which led to heart attack in the company of heart muscle deterioration.

\subsubsection{Arrhythmia}

As regular heart rhythm require appropriate oxygen supply although reduced oxygen causes improper co-ordination of electrical impulses in heart with heart beats with resultant irregular heart rate.

\subsubsection{Heart failure}

Myocardial ischemia causes damage to myocardium, thus lessening its ability to pump blood effectively which results in myocardial infarction or heart failure.

\subsection{Treatment protocol for ischemia}

Recently numerous therapeutic approaches for treating myocardial ischemia are available including lifestyle changes for instance weight reduction, increased physical activity, smoking cessation, decreased salt and fat intake along with pharmacological interven- tions such as anti-platelet agents, angiotensin converting enzyme inhibitors, statins, $\beta$-blockers, nitrates, calcium channel blockers in company with surgical revascularization like coronary artery bypass grafting and percutaneous methods (balloon angioplasty, bare-metal stents, drug eluting stents). In addition, alternative methods for reducing anginal pain such as spinal cord stimulation as well as externally enhanced counter pulsation are also offered as given in (Table $2 \& 3$ ). Despite of these treatment strategies, patients with ischemic heart disease usually require combination therapy and persist to experience symptoms (Gibbons et al. 2003) Therefore, conventional therapy needs to be improved; while newer strategies to enhance myocardial blood flow by instigating formation of collateral vessels around obstructed coronary arteries are also in development. These approaches include treatment with recombinant growth factor proteins, transfer of growth factor genes and stem cell therapy. It is anticipated that these approaches will safely and effectively reduce myocardial ischemia, providing a promising option for patients with CHD.

\subsection{Drug targets in therapy of ischemia}

LDL cholesterol synthesis, oxidation of LDL, immune cell (monocytes/macrophages) recruitment, foam cells, (platelets aggregation), cytokines and extracellular matrix comprising of smooth muscle cells have been found to be the promising targets of treatment as evident from ischemic pathophysiology as shown in (Fig.6)(Calvez et al. 2010).

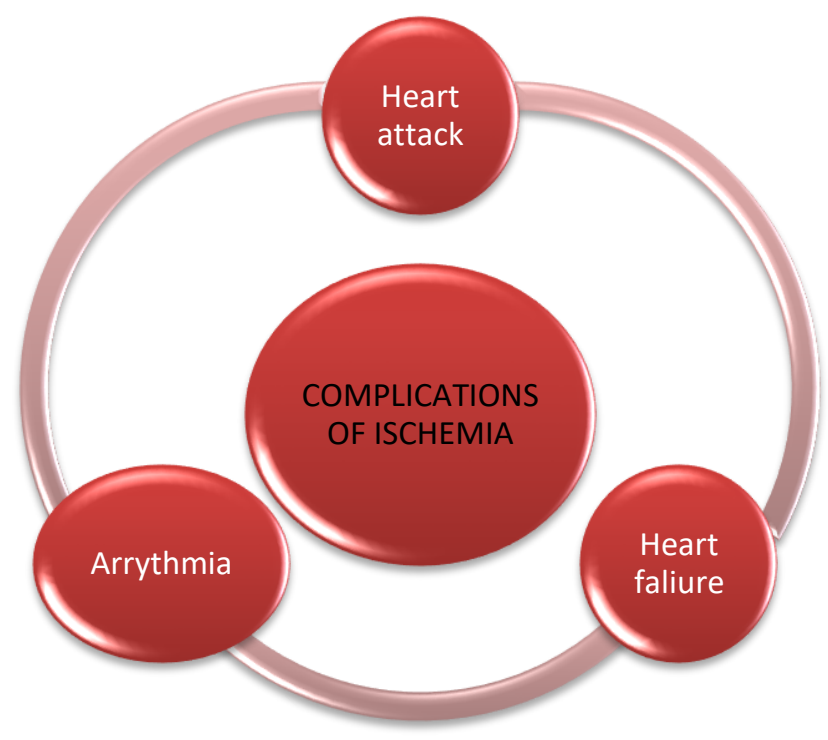

Fig. 5: Associated Complications of Myocardial Ischemia.

Table 3: Therapeutic Interventions in Myocardial Ischemia

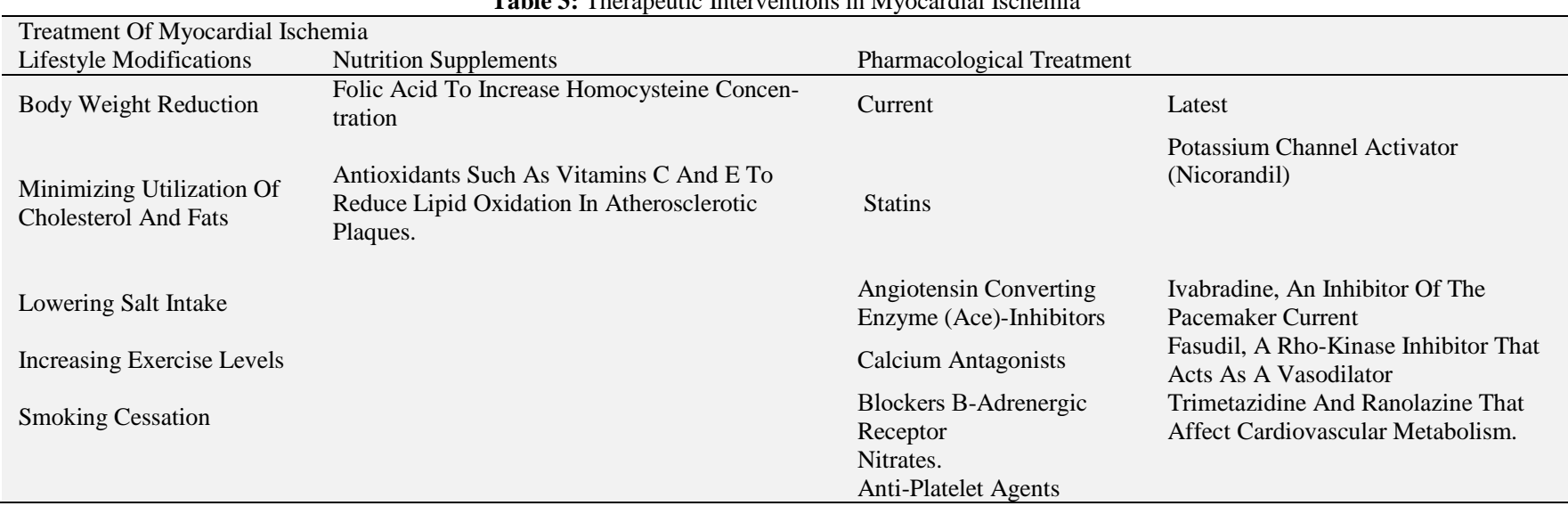


Table 4: Undesirable Profile of Recent Pharmacological Therapeutic Modalities

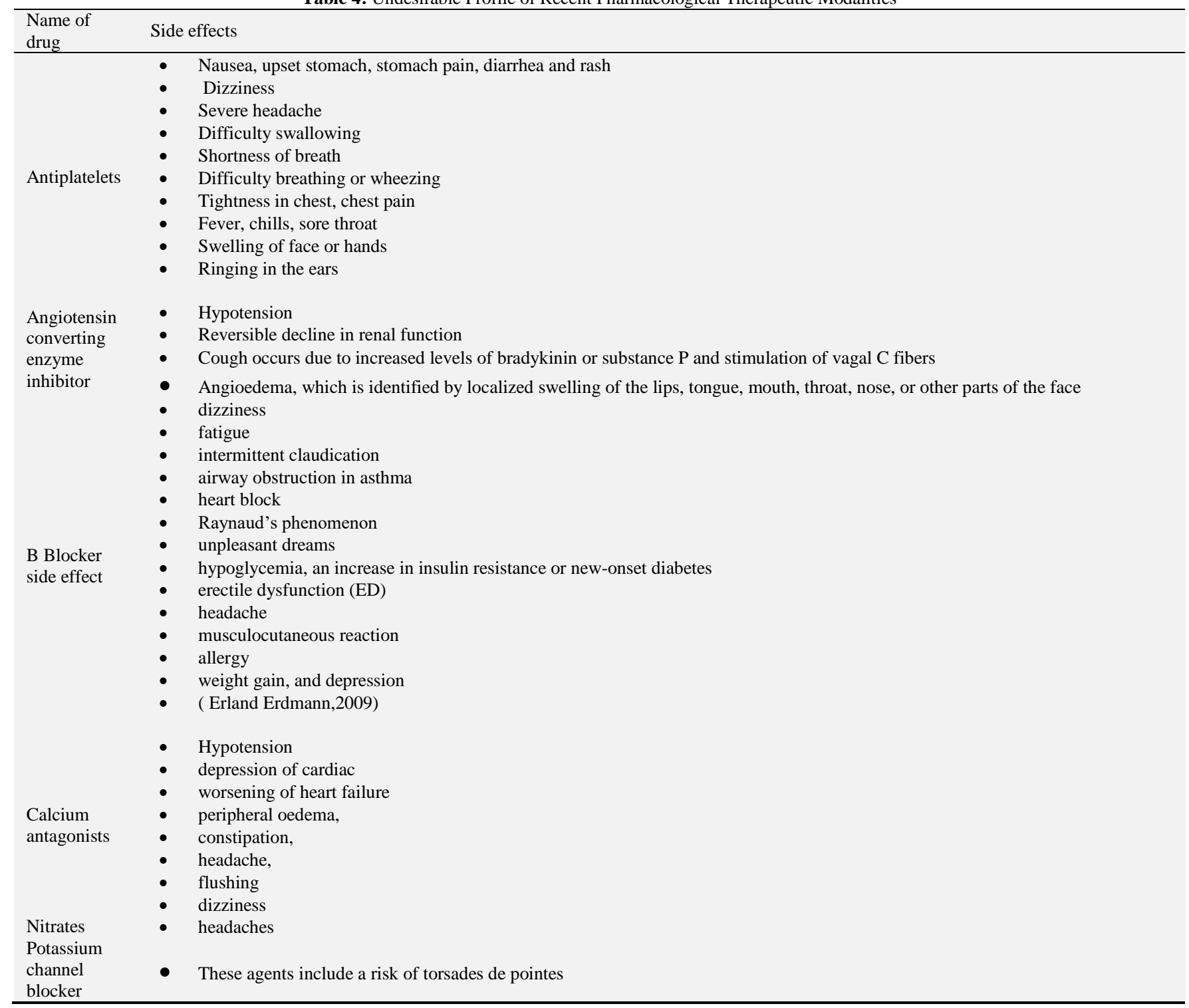

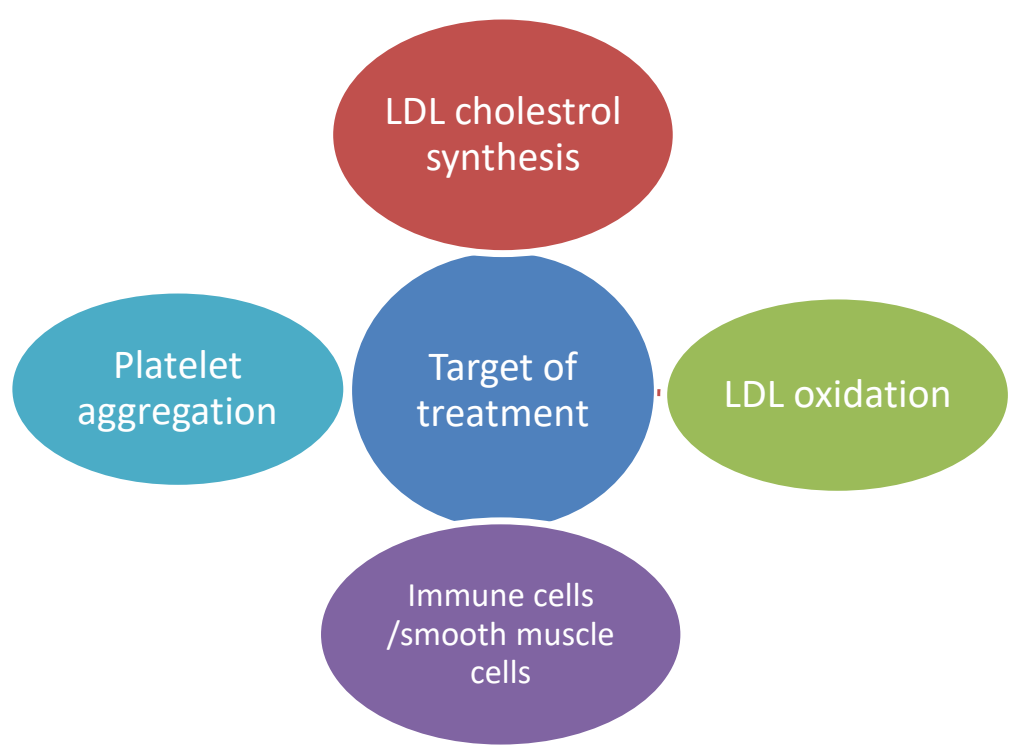

Fig.6: Drug Targets for Therapy of Ischemia.

\subsection{Narrative targets in cholesterol biosynthesis and inflam- matory pathway}

As atherosclerotic plaque formation is highly multifaceted process owing to structural and functional changes in endothelial cells, smooth muscle cells, monocytes/macrophages, T-lymphocytes and platelets. Thus, plaque growth in coronary arteries together with plaque rupture in peripheral vasculature triggers the onset of acute ischemic events. Even though, statins are well known as an imperative treatment for atherosclerosis but limited therapeutic effects 
afar from decreasing lipid levels have created a focal point to develop newer drugs to unswervingly target the process of atherosclerosis. Therefore, renin angiotensin aldosteron pathway barricade, increased nitric oxide availability, decreased calcium diffusion, alleviation of inflammation as well as oxidative stress, platelet activation together with smooth muscle cell proliferation have been established as narrative drug targets to regulate growth, expansion and thus management of atherosclerosis. Likewise, a combination therapy affecting different targets in the development of atherosclerotic plaque is a propitious challenge for future drug development (Saini et al. 2005). Moreover, hampering cholesterol production by inhibiting different enzymes, inhibiting lipid peroxidation, preventing thrombus formation by vasodilatation and platelet aggregation inhibition, reduced myocardial oxygen demand by slowing down heart rate, pressure, contractility by de- creasing calcium diffusion together with augmented myocardial perfusion.

Previous studies have reported that inflammatory aspects of atherosclerosis, particularly, C-reactive protein has drawn particular consideration owing to its role as an inflammatory marker of atherosclerosis. Likewise, inhibitors of acyl-coenzyme A, cholesterol acyltransferase, acyl-coenzyme A, diacylglycerol acyltransferase and cholesteryl ester transfer protein inhibitors, probable narrative antioxidants other than anti-inflammatory peroxisome proliferator activated receptor agonists and apolipoprotein A-I mimetic peptides might be the narrative targets for atherosclerotic intervention for improving existing therapy of ischemic events as portrayed in (Fig. 7)(Chhabria et al. 2006).

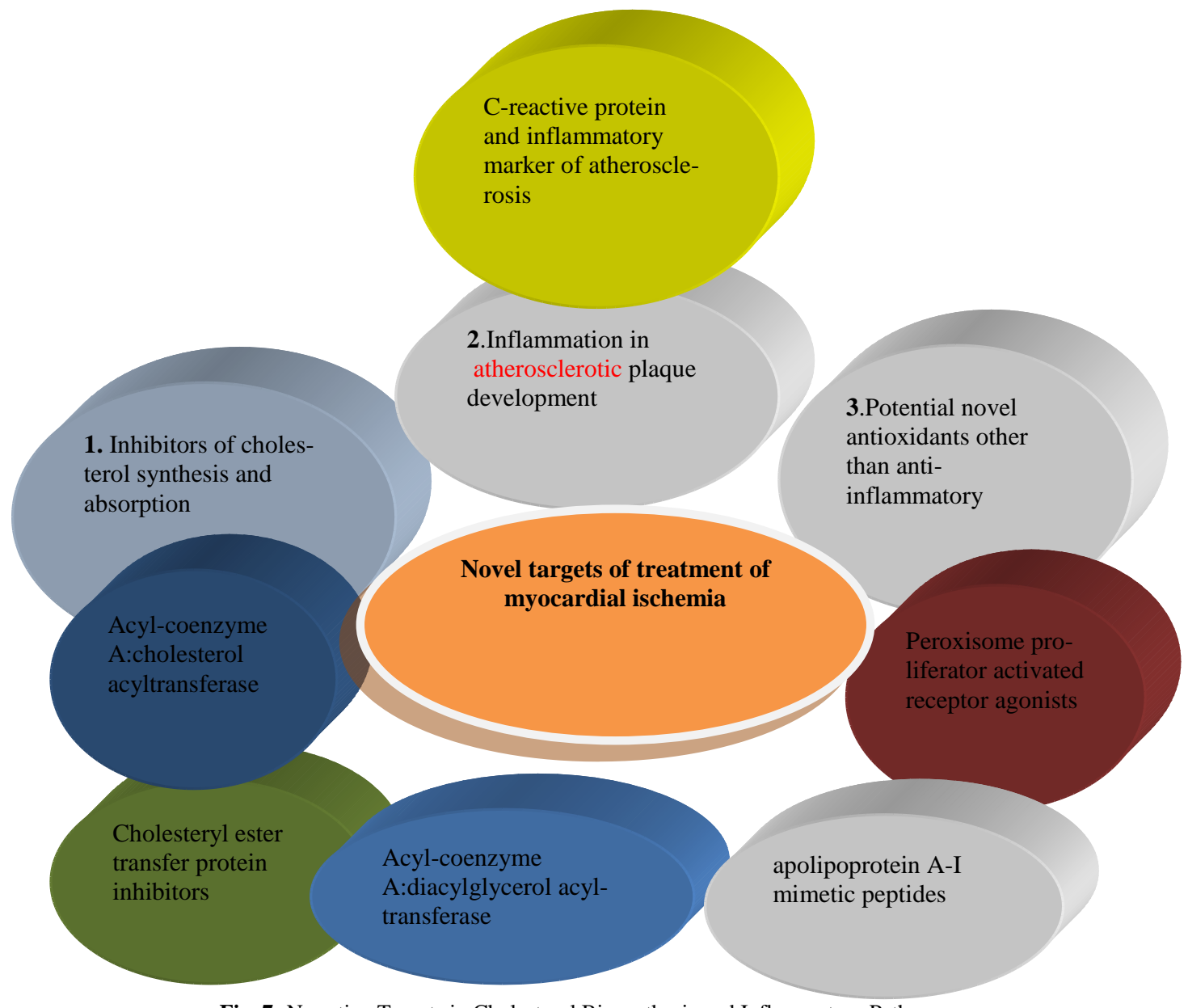

Fig. 7: Narrative Targets in Cholesterol Biosynthesis and Inflammatory Pathway.

\subsubsection{Macrophages: main targets for the management of ath-} erosclerosis

Recently, atherosclerosis has been documented as a chronic inflammatory disease going on arterial wall leading to peripheral vascular disease, myocardial infarction and stroke. Recruitment and differentiation of monocytes into functionally active macrophages in sub-endothelial space of large arteries is a crucial step in atherogenesis and macrophage accretion within plaques is a feature of all stages of atherosclerosis. Moreover, activated macrophages accumulate lipids in the company of effector molecules (pro-inflammatory, cytotoxic and chemotactic factors) expression. Moreover, macrophage secretes extracellular matrix degrading enzymes with resultant plaque destabilization and peril of rupture. Macrophages are diverse bodies which on apposite activation have the potential to drive tissue remodelling with vascular refurbish Thus, fine tuning of macrophage activities might be a highly valuable pharmacological strategy for the prevention and treatment of atherosclerosis and other inflammatory diseases (Wilson et al. 2009). Thus this review will provide the basis for highlighting already available and future methods to exploit specifically activated macrophages as diagnostic and therapeutic targets for atherosclerosis.

\subsubsection{ATP-loaded liposomes: a narrative target for treatment}

It has been demonstrated that it is difficult to effectively deliver ATP to ischemic myocardium with apposite protection from dilapidation by plasma endonucleotidases. Though, optimize encapsulation of ATP in liposomes by increasing their circulation time and target injured myocardial cells with liposomal surface anti-myosin antibody augment their effectiveness. Moreover, ex vivo studies in an isolated ischemic rat heart model and in vivo studies of rabbits with an induced myocardial infarction have been performed for these ATP liposomal preparations with an expectation that these methods will provide a origin for continued studies of effective 
ways to carry energy substrates to the ischemic myocardium. (Levchenko et al. 2010).

There is a growing population of patients who have received conventional medical and revascularization therapies but still have anginal symptoms. For these patients, there are numerous other therapeutic modalities that may be considered as adjuncts to conventional therapies, including spinal cord stimulation, enhanced extracorporeal counterpulsation, and transmyocardial revascularization.

\section{Need to develop new drugs}

As a result of improved survival for patients with coronary disease, there is a growing population of patients who have exhausted conventional medical and revascularization therapies and still have anginal symptoms. For these patients, there are therapies that may be considered as adjuncts to conventional therapies. These treatment modalities may include spinal cord stimulation, enhanced extracorporeal counterpulsation, and transmyocardial revascularization.

\section{Drugs of ethnobotanical origin}

In spite of spectacular advances in synthetic drugs in recent years, some of the drugs of plant origin have still retained their importance. Since, plants have been endowed with variety of phytotherapeutic agents who might serve as lead compounds for the development of novel drugs. Moreover, herbal medicines are now being preferred over modern allopathic drugs owing to their cultural acceptability and compatibility. Moreover, customary medicinal herbs offer a great source of bioactive compounds and then their development into new valuable drugs for management of number of human ailments. Furthermore, use of plant based drugs in western world is increasing, and this is because of the belief that many herbal medicines are known to be free from side effects and from the fact that the discovery of the new synthetic drug is time consuming and expensive affair (Ramachandrayl et al. 2012) Similarly, numerous medicinal plants have been used traditionally in ischemic heart events as given in (Table 5).

Table 5: Plants Having Protective Effect in Myocardial Ischemia

\begin{tabular}{|c|c|c|c|}
\hline Plant name & Family & Part use & References \\
\hline $\begin{array}{l}\text { Urtica parviflo- } \\
\text { ra }\end{array}$ & Urticaceae & Leaves & $\begin{array}{l}\text { (Barman et al. } \\
\text { 2013) }\end{array}$ \\
\hline Aegle marmelos & Rutaceae & $\begin{array}{l}\text { Leaves stem } \\
\text { bark, flowers } \\
\text { and root }\end{array}$ & $\begin{array}{l}\text { (Prince \& Raja- } \\
\text { durai, 2005). }\end{array}$ \\
\hline $\begin{array}{l}\text { Evolvulus } \\
\text { alsinoides. Linn }\end{array}$ & Convolvulaceae & Leaves & $\begin{array}{l}\text { (Sudhakumari et } \\
\text { al. 2012) }\end{array}$ \\
\hline $\begin{array}{l}\text { Trichopus } \\
\text { zeylanicus }\end{array}$ & Dioscoreaceae & Leaves & $\begin{array}{l}\text { (Velavan et al. } \\
\text { 2009) }\end{array}$ \\
\hline $\begin{array}{l}\text { Cucumis } \\
\text { trigonus }\end{array}$ & Cucurbitaceae & Fruit & $\begin{array}{l}\text { (Thippeswamy } \\
\text { et al. 2009) }\end{array}$ \\
\hline $\begin{array}{l}\text { Terminalia } \\
\text { arjuna }\end{array}$ & Combretaceae & Bark & $\begin{array}{l}\text { (Karthikeyan et } \\
\text { al. 2003) }\end{array}$ \\
\hline $\begin{array}{l}\text { Salvia miltior- } \\
\text { rhiza }\end{array}$ & Lamiaceae & Stem,flower & $\begin{array}{l}\text { (Zhao et al. } \\
1996)\end{array}$ \\
\hline $\begin{array}{l}\text { Psidium guaja- } \\
\text { va } L .\end{array}$ & Myrtaceae & Fruit & $\begin{array}{l}\text { (Yamashiro et } \\
\text { al. 2003) }\end{array}$ \\
\hline $\begin{array}{l}\text { Astragalus } \\
\text { membranaceus }\end{array}$ & Fabaceae & Root & $\begin{array}{l}\text { (Zhou et al. } \\
2000 \text { ) }\end{array}$ \\
\hline $\begin{array}{l}\text { Desmodium } \\
\text { gangeticum }\end{array}$ & Fabaceae & Root & $\begin{array}{l}\text { (Kurian et al. } \\
\text { 2010) }\end{array}$ \\
\hline $\begin{array}{l}\text { Emblica } \\
\text { officinalis }\end{array}$ & Phyllanthaceae & Fruit & $\begin{array}{l}\text { (Rajak et al. } \\
\text { 2004) }\end{array}$ \\
\hline $\begin{array}{l}\text { Hibiscus rosa } \\
\text { sinensis }\end{array}$ & Malvaceae & Flowers & $\begin{array}{l}\text { (Gauthaman et } \\
\text { al. 2014) }\end{array}$ \\
\hline $\begin{array}{l}\text { Sida Rhombifo- } \\
\text { lia Linn. }\end{array}$ & Malvaceae & Whole plant & $\begin{array}{l}\text { (Ramadoss et al. } \\
\text { 2012) }\end{array}$ \\
\hline Medicago sativa & Fabaceae & Stem & $\begin{array}{l}\text { (Gomathi et al. } \\
\text { 2014) }\end{array}$ \\
\hline
\end{tabular}

\begin{tabular}{|c|c|c|c|}
\hline Panax japonicas & Araliaceae & Whole plant & (He et al. 2014) \\
\hline $\begin{array}{l}\text { Croton sparci- } \\
\text { florus }\end{array}$ & Euphorbiaceae & Whole plant & $\begin{array}{l}\text { (Beaulah et al. } \\
\text { 2014) }\end{array}$ \\
\hline $\begin{array}{l}\text { Andrographis } \\
\text { paniculata }\end{array}$ & Acanthaceae & Whole herb & $\begin{array}{l}\text { (Ojha et al. } \\
\text { 2012) }\end{array}$ \\
\hline $\begin{array}{l}\text { Lavandula } \\
\text { angustifolia }\end{array}$ & Lamiaceae & $\begin{array}{l}\text { Aerial parts of } \\
\text { plants }\end{array}$ & $\begin{array}{l}\text { (Ziaee et al. } \\
2005 \text { ) }\end{array}$ \\
\hline Ginkgo biloba & Ginkgoaceae & Leaves & $\begin{array}{l}\text { (Shen \& Zhou } \\
\text { 1995) }\end{array}$ \\
\hline $\begin{array}{l}\text { Hydrocotyle } \\
\text { asiatica Linn. }\end{array}$ & Apiaceae & Whole plant & $\begin{array}{l}\text { (Pragada et al. } \\
\text { 2004) }\end{array}$ \\
\hline $\begin{array}{l}\text { Tinospora cor- } \\
\text { difolia }\end{array}$ & Menispermaceae & Whole plant & $\begin{array}{l}\text { (Rao et al. } \\
2005 \text { ) }\end{array}$ \\
\hline $\begin{array}{l}\text { Salvia miltior- } \\
\text { rhiza, }\end{array}$ & Labiatae & Stem/leaves & $\begin{array}{l}\text { (Yagi et al. } \\
1989 \text { ) }\end{array}$ \\
\hline $\begin{array}{l}\text { Limonium } \\
\text { wrightii }\end{array}$ & Plumbaginaceae & & $\begin{array}{l}\text { (Yamashiro et } \\
\text { al. 2003) }\end{array}$ \\
\hline Curcuma longa & Zingiberaceae & Root & $\begin{array}{l}\text { (Mohanty et al. } \\
\text { 2004) }\end{array}$ \\
\hline
\end{tabular}

\section{Conclusion}

Ischemic heart disease is a distressing condition leading to irreversible myocardial failure. In this review, an attempt has been made to give better understanding of pathophysiology of chronic ischemic disease and to highlight targets for narrative therapeutic approaches with an intention to increase patient's life span.

\section{References}

[1] Bhatti IP, Lohano HD, Pirzado ZA, \& Jafri IA (2006) A logistic regression analysis of the Ischemic Heart Disease Risk. Journal of $\begin{array}{llll}\text { Applied } \quad \text { Sciences 6, 785-788. } & \text { 6, }\end{array}$ https://doi.org/10.3923/jas.2006.785.788.

[2] Barman NR, Nandy S, Datta R, \& Kar PK (2013) Cardioprotective effect of ethanolic extract of Urtica parviflora Roxb. Against isoproterenol induced myocardial infarction in rats. Indian journal of pharmacology 45, 513-516. https://doi.org/10.4103/02537613.117782.

[3] Beaulah A, Mohamed SA \& Sivakumar V (2014) Cardioprotective activity of methanolic extract of Croton sparciflorus on isoproterenol induced myocardial infarcted wistar albino rats. Journal of Medicinal Plants 2, 01-08.

[4] Calvez V, Ebde A, Meunier N, \& Raoult A (2009) Mathematical modelling of the atherosclerotic plaque formation. In ESAIM: Proceedings 28, 1-12. https://doi.org/10.1051/proc/2009036.

[5] Chhabria MT \& Brahmkshatriya PS (2006) Novel targets for the treatment of atherosclerosis. Current Opinion in Investigational Drugs 7, 820-825.

[6] Erdmann E. (2009). Safety and tolerability of beta-blockers: prejudices and reality. European Heart Journal 11, A21-A25 doi:10.1093/eurheartj/sup001

[7] Gibbons RJ, Abrams J, Chatterjee K, Daley J, Deedwania PC, Douglas JS \& O'Rourke RA (2003) ACC/AHA 2002 guideline update for the management of patients with chronic stable angina. Journal of the American College of Cardiology 41, 159-168. https://doi.org/10.1016/S0735-1097(02)02848-6.

[8] Gauthaman KK, Saleem MT, Thanislas PT, Prabhu VV, Krishnamoorthy KK, Devaraj NS \& Somasundaram JS (2006) Cardioprotective effect of the Hibiscus rosa sinensis flowers in an oxidative stress model of myocardial ischemic reperfusion injury in rat. BMC Complementary and Alternative Medicine 6, 1-8. https://doi.org/10.1186/1472-6882-6-32.

[9] Gomathi R, Vijipriya M, \& Usha K (2014) Cardio protective effect of ethanolic extract of Medicago sativa stem on isoproterenol induced myocardial infarction in Wistar Albino rats. International Journal of Pharmacy and Pharmaceutical Sciences 6, 839-842.

[10] He H, Xu J, Xu Y, Zhang C, Wang H, He Y \& Yuan D (2012) Cardioprotective effects of saponins from Panax japonicus on acute myocardial ischemia against oxidative stress-triggered damage and cardiac cell death in rats. Journal of ethnopharmacology 140, 73-82. https://doi.org/10.1016/j.jep.2011.12.024.

[11] Karthikeyan K, Bai BS, Gauthaman K, Sathish KS, \& Devaraj SN (2003) Cardioprotective effect of the alcoholic extract of Terminalia arjuna bark in an in vivo model of myocardial ischemic reperfusion injury. Life sciences 73, 2727-2739. https://doi.org/10.1016/S0024-3205(03)00671-4. 
[12] Kurian GA, Suryanarayanan S, Raman A, \& Padikkala J (2010) Antioxidant effects of ethyl acetate extract of Desmodium gangeticum root on myocardial ischemia reperfusion injury in rat hearts. Chinese medicine 5, 2-7 https://doi.org/10.1186/1749-8546-5-3.

[13] Libby P \& Theroux P (2005) Pathophysiology of coronary artery disease. Circulation 111, 3481-3488. https://doi.org/10.1161/CIRCULATIONAHA.105.537878.

[14] Levchenko TS, Hartner WC, Verma DD, Bernstein EA \& Torchilin VP (2010) ATP-loaded liposomes for targeted treatment in models of myocardial ischemia. Liposomes: Methods and Protocols, Pharmaceutical Nanocarriers 1, 361-375. https://doi.org/10.1007/978-160327-360-2 25.

[15] Mohanty I, Arya DS, Dinda A, Joshi S, Talwar KK \& Gupta SK (2004) Protective effects of Curcuma longa on ischemiareperfusion induced myocardial injuries and their mechanisms. Life sciences 75, 1701-1711. https://doi.org/10.1016/j.lfs.2004.02.032.

[16] Murray CJ \& Lopez AD (1996) Evidence-based health policylessons from the Global Burden of Disease Study. Science 274, 740-743. https://doi.org/10.1126/science.274.5288.740.

[17] Ojha SK, Bharti S, Joshi S, Kumari S \& Arya DS (2012) Protective effect of hydroalcoholic extract of Andrographis paniculata on ischaemia-reperfusion induced myocardial injury in rats. The Indian journal of medical research 135, 414-421.

[18] Pragada RR, Veeravalli KK, Chowdary KPR \& Routhu KV (2004) Cardioprotective activity of Hydrocotyle asiatica L. in ischemiareperfusion induced myocardial infarction in rats. Journal of ethnopharmacology93,105-108. https://doi.org/10.1016/j.jep.2004.03.025

[19] Prince P \& Rajadurai M (2005) Preventive effect of Aegle marmelos leaf extract on isoprenaline-induced myocardial infarction in rats: biochemical evidence. Journal of pharmacy and pharmacology 57, 1353-1357. https://doi.org/10.1211/jpp.57.10.0015.

[20] Rajak S, Banerjee SK, Sood S, Dinda AK, Gupta YK, Gupta SK \& Maulik SK (2004) Emblica officinalis causes myocardial adaptation and protects against oxidative stress in ischemic-reperfusion injury in rats. Phytotherapy Research 18, 54-60. https://doi.org/10.1002/ptr.1367.

[21] Ramachandra Y, Ashajyothi C \& Padmalatha R (2012) Cardio protective effect of aegle marmelos on isoproterenol induced myocardial infarction in rats. International journal of Biology, Pharmnacy and Applied sciences 1, 718-729

[22] Ramadoss S, Kannan K, Balamurugan K, Jeganathan NS \& Manavalan R (2012) "Efficacy of Cardioprotective Effects in Ethanolic Extract of Sida Rhombifolia Linn. On Isoproterenol-Induced Myocardial Infarction in Albino Rats. Research Journal of Pharmaceutical, Biological and Chemical Sciences 3, 488-493.

[23] Rao PR, Kumar VK, Viswanath RK \& Subbaraju GV (2005) Cardioprotective activity of alcoholic extract of Tinospora cordifolia in ischemia-reperfusion induced myocardial infarction in rats. Biological and Pharmaceutical Bulletin 28, 2319-2322. https://doi.org/10.1248/bpb.28.2319.

[24] Shen JG \& Zhou DY (1995) Efficiency of Ginkgo biloba extract (EGb 761) in antioxidant protection against myocardial ischemia and reperfusion injury. Biochemistry and molecular biology international 35, 125-134

[25] Pepine CJ \& Nichols WW (2007) the pathophysiology of chronic ischemic heart disease. Clinical cardiology 30, I-4. https://doi.org/10.1002/clc.20048.

[26] Saini HK, Xu YJ, Arneja AS, Tappia PS \& Dhalla NS (2005) Pharmacological basis of different targets for the treatment of atherosclerosis. Journal of cellular and molecular medicine 9, 818-839. https://doi.org/10.1111/j.1582-4934.2005.tb00382.x.

[27] Singhal A \& Lucas A (2004) early origins of cardiovascular disease: is there a unifying hypothesis? The Lancet 363, 1642-1645. https://doi.org/10.1016/S0140-6736(04)16210-7.

[28] Tomkin GH \& Owens D (2012) LDL as a cause of atherosclerosis The Open Atherosclerosis \& Thrombosis Journal 5, 13-21 https://doi.org/10.2174/1876506801205010013.

[29] Sudhakumari A, Javed A, Jaiswal M \& Talkad MS (2012) Cardioprotective Effects in Methanolic Extract of Evolvulus Alsinoides Linn on Isoproterenol-Induced Myocardial Infarction in Albino Rats. International Journal of Basic Medical Sciences and Pharmacy (IJBMSP) 2, 53-57.

[30] Thippeswamy BS, Thakker SP, Tubachi S, Kalyani GA, Netra MK, Patil U \& Veerapur VP. (2009). Cardioprotective effect of Cucumis trigonus Roxb on isoproterenol-induced myocardial infarction in rat. American journal of pharmacology and toxicology 4, 29-37. https://doi.org/10.3844/ajptsp.2009.29.37.

[31] Velavan S, Selvarani S \& Adhithan a (2009) Cardioprotective effect of Trichopus zeylanicus against myocardial ischemia induced by isoproterenol in rats. Bangladesh Journal of Pharmacology 4 88-91. https://doi.org/10.3329/bjp.v4i2.1824.

[32] Wilson HM, Barker RN \& Erwig LP (2009) Macrophages: promising targets for the treatment of atherosclerosis. Current vascular pharmacology 7 , 234-243. https://doi.org/10.2174/157016109787455635.

[33] Yusuf S, Reddy S, Ôunpuu S \& Anand S (2001) Global burden of cardiovascular diseases part I: general considerations, the epidemiologic transition, risk factors, and impact of urbanization. Circulation 104, 2746-2753. https://doi.org/10.1161/hc4601.099487.

[34] Yagi A, Fujimoto K, Tanonaka K, Hirai K \& Takeo S (1989) Possible aktive components of Tan-Shen (Salvia miltiorrhiza) for protection of the myocardium against ischemia-induced derangements. Planta medica 55, 51-54. https://doi.org/10.1055/s-2006-961824

[35] Yamashiro S, Noguchi K, Matsuzaki T, Miyagi K, Nakasone J, Sakanashi M \& Aniya Y (2003) Cardioprotective effects of extracts from Psidium guajava L. and Limonium wrightii, Okinawan medicinal plants, against ischemia-reperfusion injury in perfused rat hearts. Pharmacology 67 , $128-135$. https://doi.org/10.1159/000067799.

[36] Zhao BL, Jiang W, Zhao Y, Hou JW \& Xin WJ (1996) Scavenging effects of salvia miltiorrhiza on free radicals and its protection for myocardial mitochondrial membranes from ischemia-reperfusion injury. Biochemistry and molecular biology international 38, 11711182.

[37] Zhou JY, Fan Y, Kong JL, Wu DZ \& Hu ZB (2000) Effects of components isolated from Astragalus membranaceus Bunge on cardiac function injured by myocardial ischemia reperfusion in rats]. Zhongguo Zhong yao za zhi= Zhongguo zhongyao zazhi= China journal of Chinese materia medica 25, 300-302.

[38] Ziaee M, Khorrami A, Ebrahimi M, Nourafcan H, Amiraslanzadeh M, Rameshrad M \& Garjani A (2015) Cardioprotective effects of essential oil of Lavandula angustifolia on isoproterenol-induced acute myocardial infarction in rat. Iranian journal of pharmaceutical research: IJPR 14, 279-289. 